\title{
Problemas para el estudio de la historia regional: El caso del Cusco Luis Miguel Glave
}

uien hoy día visite el Cusco podrá comprobar, con una ligera percepción del acontecer cotidiano, que en sus habitantes pervive un sentimiento regional, que parece ser característica común de otros centros regionales como Arequipa, Iquitos o Huánuco, por mencionar algunos ejemplos. Basta sintorizar una audición radial para escuchar alternativamente lemas como: "El Cusco es una ciudad llamada a mejores destinos", o "el Cusco sólo se podrá desarrollar con una descentralización efectiva". Cualquier problema regional encontrará en los comentarios radiales la causa común de todos: el centralismo limeño. Este regionalismo cusqueño muestra particulares características, más complejas que las de otras expresiones similares en este país. No sólo es partícipe el Cusco de la más definida región del Perú, el Sur ${ }^{1}$; sino que dentro de esta gran región representa un propio perfil, una clara y diferente alternativa.

Hace 50 años Mariátegui afirmó que el regionalismo se expresaba en el Perú como un "malestar". 2 Hoy parece que las cosas no han cambiado y que aquella afirmación está nutrida de certeza y continuidad. Pero ese malestar, de manera paulatina y sin continuidad, viene desarrollando canales de expresión colectiva, orgánica. Bástenos recordar, para ilustrar esto, los últimos años en donde un movimiento no coordinado y espontáneo fue presentando ante el país, nuevamente, la reivindicación regional cusqueña.

En 1977 se abrió un período crítico para el Gobierno Militar de entonces. El primer paro general obrero de dimensiones nacionales de nuestra historia fue el indicador más claro de crisis, y el preludio de los cambios que hoy todos conocemos. Ese mismo 
año, las "explosiones" regionales marcaron la escena política nacional y manifestaron que las provincias no sólo participaban de una movilización nacional de protesta sino que tenian una propia problemática por la cual reclamar.

El Cusco fue el ejemplo más claro y más constante de este nuevo regionalismo, sus protestas fueron la antesala del 19 de julio de 1977, fecha del paro nacional. Durante 3 días, 15, 16 y 17 de junio, la ciudad se paralizó, los caminos se interrumpieron y la violencia estuvo presente de principio a fin. Junto con la protesta contra el alto costo de vida y otras reivindicaciones laborales, en las banderas de lucha de obreros, empleados y campesinos así como de estudiantes y profesores, estaban presentes demandas regionales como ferrocarril a Quillabamia, ampliación de la central hidroeléctrica de Machu Picchu, Hospital, asfaltado de carreteras a Nazca y Puno, etc. . . En el calor de esa reciente movilización y la persecución policíaco-militar que el régimen desató, los sectores populares del Cusco formaron un Frente Democrático Popular y Antimpcrialista (FDPA) que fue quien convocó al paro del 19 de julio que se efectivizó con todo éxito en el departamento.

Pero no era esto suficiente para solucionar los problemas que aquejaban a los obreros y campesinos, y menos para aquellos que hacian más patente el aislamiento regional y la pobreza de su estructura productiva. Es más, el régimen militar respondió con despidos, persecuciones y sobre todo con oidos sordos a las reivindicaciones regionales.

En esa coyuntura, el más representativo conjunto de organizaciones populares del Cusco, declaró fundado, el 17 de octubre de 1977, el Comité Coordinador de Organizaciones Populares (COCOP), nominando al joven dirigente de los empleados de la Universidad, el Sr. Elmer Abarca, como primer presidente. Al margen de las diferencias políticas que impulsaron a la izquierda a aglutinarse en un nuevo organismo, reemplazante del FDPA; la nueva entidad popular significaba verdaderamente una expresión orgánica del conjunto del pueblo cusqueño, y ese mérito fue reconocido en todas las publicaciones no oficialistas que aparecieron por ese entonces.

Al poco tiempo, el COCOP convoca a una "Gran Asamblea Popular" en la Plaza de Armas. Ahí fue claro un sentimiento que movilizaba las bases más allá de muchas consignas: el regionalismo. 
Por eso no fue extraño que el hecho, o error, de organizar la Conferencia Anual de Ejecutivos (CADE) en Cusco, desencadenara la tercera gran paralización del año en la ciudad. En una ciudad donde las industrias son tan exiguas y poco prometedoras, donde las altas inversiones turísticas contrastan con la carencia de crédito para la agricultura y donde los dirigentes están acostumbrados a hacerse oír, era demasiado que se organizara un encuentro nacional de industriales y que el entonces Ministro del ramo, Gral. Ibáñez O'Brien se negara a escuchar las demandas populares y regionales que los dirigentes del COCOP llevaron al CADE. Los dirigentes hablaron de "insultos a la región" por parte del General Ministro y, los días 22 y 23 de noviembre, ordenaron paralización de actividades.

Uno de los gobiernos más centralistas y centralizadores ha sido sin duda el de los militares que gobernaron de 1968 a 1980. Por eso, uno de los movimientos populares más claramente regionalista fue ese de 1977-78 en el Cusco encabezado por el hoy desaparecido COCOP. La fuerza del movimiento puede verse en el hecho de que los militares tuvieran que acceder a escuchar a los cusqueños. Un "Cabildo Abierto" transmitido por Radio Cusco a todo el departamento se efectuó el 8 de diciembre ante un apurado Ministerio del Interior. El COCOP y todos sus miembros hicieron escuchar varias horas de quejas al General Cisneros Vizquerra. Casi por cansancio, el ministro ofreció un conjunto de obras y medidas para calmar la protesta regional que en ese entonces hegemonizaba el pueblo cusqueño. Hasta hoy, el coliseo cerrado o "Casa de la Juventud" es la única promesa cumplida.

El recuerdo de la personalidad regional alcanzada por el Cusco en ese año de enfrentamientos aún persiste en el pueblo, pero con un detalle más de importancia. En 1978, el 19 de octubre, otro Cabildo Abierto fue convocado por las incumplidas reivindicaciones regionales. De ahí salió un organismo más bien burocrático, el FUDESO, Frente Unitario de Defensa y Desarrollo del Sur Oriente. Esta vez el pueblo estuvo subordinado a la élite dominante regional. Los pronunciamientos tuvieron mejor expresión, fueron más difundidos y llegaron a escucharse en el Gobierno. No hubo huelga esta vez.

Hoy, el nuevo Gobierno se apresta hacer uso del regionalismo y sus representantes cusqueños tienen como carta de presentación el 
haber participado de ese Frente del 78 que consiguió la RegionaliZación del Instituto Nacional de Cultura y la implantación del Boleto Turístico. Pero los problemas regionales siguen latentes, nuevamente como malestar y con las clases populares sin la iniciativa sino más bien bajo la hegemonía ideológica de los más lúcidos representantes de la élite regional dominante.

Esta coyuntura muestra pues claramente cómo el regionalismo pueda adquirir diversos matices, en la medida en que incumbe a todos los grupos sociales. Pero también, el estado actual de la región, muestra que aún no ha surgido una alternativa clara de grupo sociales hegemonizados por aquél que realmente levante como suyos los reclamos regionales. Y finalmente, hoy queda claramente expresado que, salvo planteamientos obtusos o fuera de la realidad, no es el regionalismo un separatismo o un federalismo sino, todo lo contrario, parte del reclamo por hacer del Perú una nación integrada.

El propósito de estas notas es mostrar cómo este regionalismo, expresado hoy con contenidos variados de acuerdo a los grupos que lo lleven como bandera, tiene un origen histórico que es necesario desentrañar. La problemática del "desarrollo regional" que hoy preocupa a la élite dominante tanto como a las izquierdas y crganizaciones populares, no puede ser vista como terreno de la planificación burocrática o expresada simplemente como descripción presentista. Es necesario mostrar las raíces estructurales y políticas de esta región y los cambios ocurridos en el contenido de sus expresiones regionales. La identidad de los grupos que emprendan el desarrollo regional como parte de un proceso de realización e independencia nacionales, será producto de la memoria colectiva que hoy se encarne por fin en una voluntad colectiva. En esta tarea, la historia, lejos de ser un recurso académico, se convierte en el "fondeadero de la conciencia nacional popular". Rehuir el tiempo y los cambios es hacerle el juego a la burocracia, producto del centralismo; encarar históricamente el problema es quitarle el piso a toda demagogia impresionista y a todo centralismo disfrazado.

Para esto, queremos presentar como sugerencia de una futura investigación, algunas hipótesis de trabajo sustentadas en evidencias registradas por nosotros en dos años de trabajo. 


\section{LA FORMACION REGIONAL CUSQUEÑA \\ EN EL ESPACIO COLONIAL PERUANO: \\ EL CUSCO Y EL MERCADO INTERNO COLONIAL.}

\section{El Eje Lima-Potosí}

Es por todos conocido que a la llegada de los españoles, el Imperio de los Incas tenía como centro a la ciudad del Cusco. Tan dilatados territorios como los que involucraba esa formación social, estuvieron vinculados con el Cusco por una red caminera que fue, para los conquistadores, un botín tan valioso como el oro de la conquista y el pillaje inicial. Si bien es dable suponer, como lo hace R.J. Bromley, ${ }^{3}$ que los caminos indios fueron reorientados hacia las rutas del sistema colonial en formación, hacia Guayaquil por el norte y Lima en el centro, para mirar al mar y por ahí a la metrópoli; nosotros también podemos afirmar que la red caminera del Cusco a los cuatro "suyos" continuó siendo utilizada durante el período colonial sin cambios sustantivos. Para entender cómo el Cusco incaico dio paso al dominio colonial, conviene graficar un esquema del espacio y la economía coloniales de los siglos XVI y XVII.

Por distintas razones de orden histórico y por la riqueza de nuestro suelo, el espacio peruano, como todos los "reinos de Indias", estuvo destinado a proveer de metales preciosos a la metrópoli. El descubrimiento en 1545 del cerro de Potosí en el Altiplano peruano, fue el acontecimiento decisivo en la orientación de toda la estructura económica que nacía. Entenderemos entonces que el sector minero fue el sector dominante de la estructura, tanto por su incidencia en la dinamización de la formación social de la que era parte como por el interés metropolitano que dominaba externamente dicha formación social.

De acuerdo a la política imperial de la corona española, un centro político debía ser el comunicador del orden colonial. Lima cumplió esa función. Como centro político su importancia era máxima al ser sede del Virreinato además de cabeza de Audiencia. Como centro económico, la población española que congregaba requería ser abastecida con la dieta europea que pronto los valles aledaños, su hinterland, comenzaron a proveer; y todos los requerimientos de empleo urbano comenzaron a ser cubiertos. Final- 
mente. Lima fuc designada como la única entrada posible de las mercaderias europeas prohibidas de ser producidas en América y que la población blanca consumia para satisfacer los requisitos sociales que el "más valer" para el que vinieron a indias les imponia. Li sistema de monopolio comercial fue para Lima la clave de su pujanza económica.

Asi. entre uno y otro centro, entre el núcleo político y comercial. y el "motor" mincro. se tejia toda la estructura espacial y ceonomica de la colomia. Ambos se comportaron como polos de desarrollo, el cje yue conformaron será el orientador de toda la estructura. en tanto yue la pujanza o decadencia del "motor"potosino se comvertirán en moleradores de todo el conjunto económici( $)^{4}$.

(iraficamente la cestructura sera la siguicnte:

\section{GRAFICO No. 1 \\ POLO 1 \\ LIIIA \\ POLO 2 \\ POTOSI}

Centro Politico

Monopolio Comercial y

Función Comercial dependiente de la lifetrópoli.

Aglomeración demogrática
- Centro Minero

- Sector dominante del conjunto productivo.

- Aglomeración demográfica.

Hasta ahora nuestro espuema se ha movido al nivel de la producción hacia afuera. con la sola variante de la importación monopólica que es otro elemento externo aglutinante de relaciones al interior de nuestra fomación. Pero ambas ciudades y economías concitarán una polarización regional. Para nuestro caso, Cusco será una región polarizada por Potosí.

Abastecer una ciudad explosiva como Potosí fue el origen de un conjunto de articulaciones regionales que dieron origen a un mercalo interno colonial a nivel de macro escala regional. ${ }^{5}$ Es muy interesante para nuestro estudio saber que Potosí y Huancavelica otra ciudad minera que polarizó regiones en torno suyo- no se fundaron sino que se desarrollaron espontáneamente una vez descubiertas las minas en 1545 y 1563 respectivamente. Su caracte- 
rística inorganicidad se refleja en el hecho de que todos los negocios eran más gratificantes ahi donde los intercambios se hacían con plata y donde los ricos (españoles y hasta indios) no basaban su riqueza en propiedades o inversiones sino en el más fluido "cash"; los precios eran muy altos, aunque el importante y explosivo mercado de la coca haya sido saturado a fines del siglo XVI y su precio bajara ${ }^{6}$, a diferencia de las ciudades donde se imponía aranceles para los bienes de consumo. Sociedades "abiertas" y orientadas a la demanda, crecieron mucho, llegando Potosí a tener en 1573, durante un censo de Toledo, 120,000 habitantes; y al principio del siglo siguiente alrededor de 160,000 (la más grande ciudad del hemisferio occidental) según versiones menos precisas. $^{7}$

Mellafe nos dice al respecto que: "Deberíamos recordar en ese punto, para el virreinato peruano, que la red de influencia distorsionadora de Potosí, a fines del siglo XVI, llega hasta el Río de la Plata y hasta Quito por el norte, reestructurando en esta forma esquemas regionales de producción, de migraciones, y de circulación monetaria". 8 El Cusco fue una de esas economías regionales que se orientaron hacia Potosi y que, una vez consolidado el dominio español y con él la economía monetaria y mercantil, integró su región en diferentes niveles jerárquicos al mercado interno, débil y estructuralmente limitado, que el debut del siglo XVII peruano ya conocía.

\section{El Cusco como nudo regional}

La ubicación del Cusco no es un factor que pueda dejarse de lado. La ciudad estaba a mitad de camino entre Lima y Potosí, en medio del eje orientador de los espacios; muy ligada con las dos ciudades mineras, Huancavelica (que también estaba camino a Cusco) y Potosí, y en el corazón de los andes centrales donde se hallaba concentrada la más alta población indígena. ${ }^{9}$ La ciudad desde un inicio fue codiciada por los soldados-empresarios; luego, por su importancia política, fue también objeto de consideración de toda especie por parte de los grupos españoles. El hecho es que, aunque no contamos con datos al respecto sino hasta $1689^{10}$ en que tuvo, según fuentes de relativa precisión, 13,600 habitantes, la ciudad del Cusco fue la más grande del sur andino después de Po- 
tosi: cen una población incluso mayor a la registrada para fines del siglo XVII, dada la ruralización acaecida en ese siglo y de la que hablaremos más adelante. Mellafe por ejemplo habla de un promedio de cuarenta personas por casa de espanoles, si a ello agregamos los datos de abigarramiento de la población en barrios, ${ }^{11}$ y además la población flotante de indios que la ciudad sagrada atraía y de transéntes de la ruta principal del espacio peruano en su conjunto. entonces podemos calcular una población que debió tentar los 20.000 habitantes: población similar a la que tuvo en su época de decadencia, en 1846.12

Como aglomeración humana el cusco desarrolló una economía urbana y una sociedad que fue ademas eminentemente mercantil. ${ }^{13}$ Asi, al hecho de tener en Potosi la unidad polarizadora, Cus(o) anade en su propia economia urbana un sub-polo de desarrollo. La ciudad era generadora de la dinamica interna de su región. ${ }^{14} y$ en ceste caso reciclaba los circuitos de mercancias que iban a Potosí $y$ en general hacia afuera de la región. La producción de mercancias agrarias que el mercade potosino y cusqueño demandaba, or?anizi las haciendas andinas: $!^{15}$ estas empresas espanolas fueron la culminicion de un proceso en el pue las economias campesinas no pulieron mas abastecer los mercados de espanoles, abriendo las pucrtas de la agricultura mercantil para éstos que comenzaron a acaparar ticras. ${ }^{16}$ (omo correlato. frente a la taba de explotación minera yue la mita imponia. la familia campesina cambió su espacio de reprodución pasande de las unidades comunales al interior de la ya comstituda territorialidad de las empresas españolas, que vian asi colmados parte de sus requerimientos de fuerza de trabajo y oricntaban su produción al mercado ${ }^{17}$ en vias de constituciont.

(asco, region agraria, polarizada por Potosi, sub-polarizada por su propio núcleo organizador, influenciada por el polo limeño. comminiala con regiones vitales como la de Castrovirreyna-Huancavelica. Arequipa-Arica y la del Collao; tenia a su vez un conjunto "vertical" complementario de regiones agropecuarias que iban des(le la cocal (Pallcartambo) y el azúar (Amaybamoa y Abancay). pasando por los granos (Vilcanota y Anta) y frutas (Urubamba), hasta los productos ganaderos ( ()uispicanchis y Canas-Canchis) y la fumdamental producción autóctona de papas. Las unidades agrícolas y gandeleras productoras (haciendas), tuvicron expresiones tipi- 
cas diferentes de acuerdo a su especialización productiva que merecen estudios microeconómicos, esclarecedores también de la macroestructura regional. Pero siendo ésta una región eminentemente agrícola, la ciudad del Cusco era el filtro del tono económico influido por el sector minero y el capital mercantil en circulación; de manera que "la función de las grandes haciendas era mediar entre la ciudad y el campo, traer y llevar bienes, personas e ideas que eran vitales para el desarrollo de la civilización hispanoamericana". 18

Gráficamente podríamos expresar la estructura regional de la siguiente manera:

Gráfico No. 2

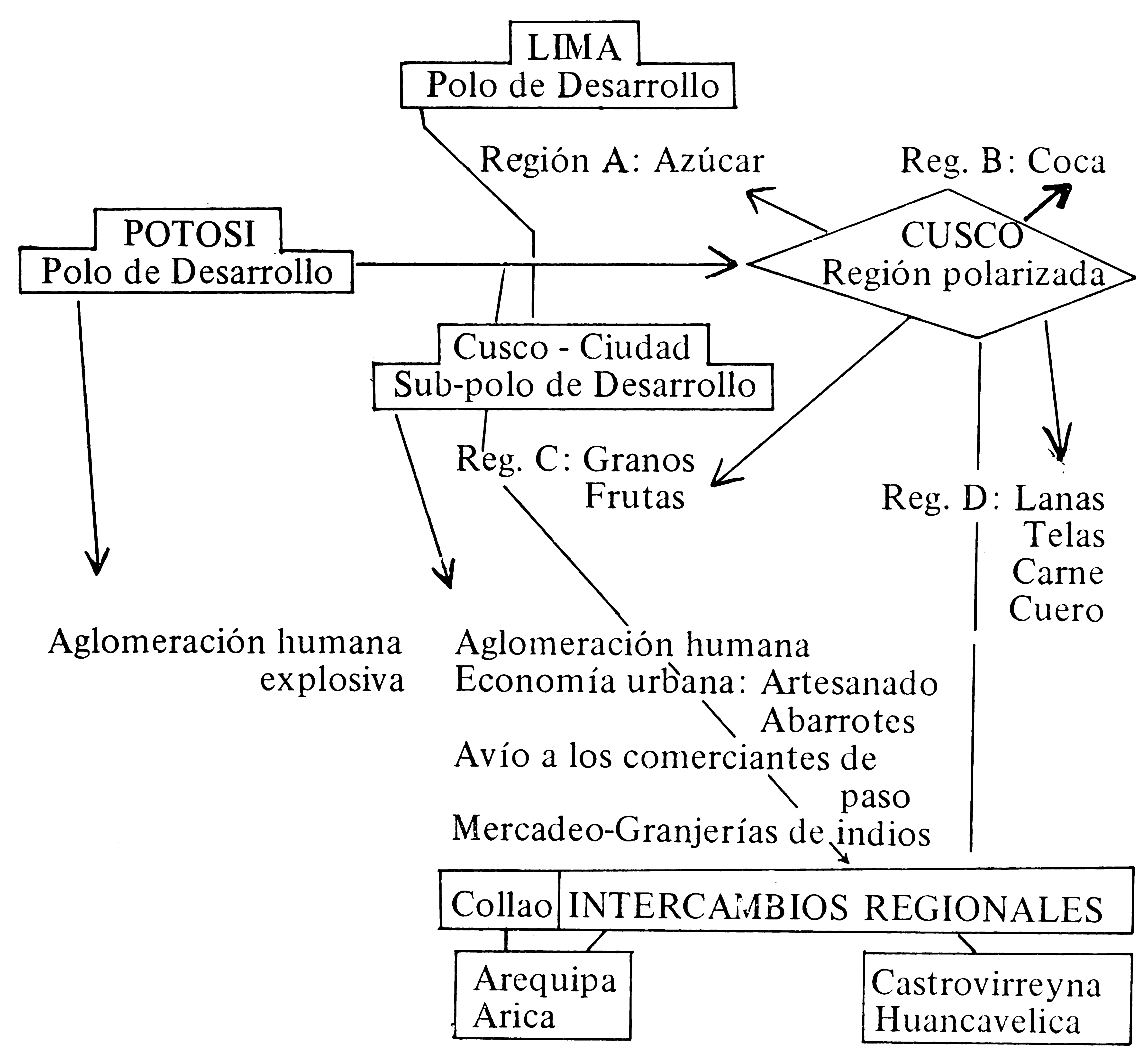




\section{Región Cusqueña y Mercado Interno Colonial}

La hipótesis de un mercado interno colonial, con todas sus limitaciones estructurales inherentes, tiene como sustento que las distintas regiones polarizadas orienten hacia afuera de sus espacios la producción comercializable, hacia el polo de desarrollo que ofrece el atractivo de intercambios con moneda o plata. Para ello, los productos valiosos que se exportan deberán ser del más fácil transporte posible. Así, por excelencia, el Cusco abastece Potosí, y las regiones tributarias de este polo de desarrollo, de coca, ${ }^{19}{ }^{1}$ azúcar $^{20}$ y telas. ${ }^{21}$ Son estos los productos del sector "moderno" de la economía agraria. Sin embargo, conviene hacer una disgresión respecto al mercado interno de los granos, sobre todo del maíz.

La región del Cusco es una provincia maicera. ${ }^{22}$ Por ejemplo el abastecimiento de otro grano como el trigo para la ciudad, era sólo un factor colateral del mercado interno; su importancia no llega a ser la de la comercialización del azúcar que incuba las más grandes fortunas. Pero el maíz no sólo es producción para abastecer ese mercado urbano, sub polo de desarrollo cusqueño, también, por la cercanía y el necesario complemento vertical de pisos ecológicos con el Collao, el maíz cusqueño era parte del mercado interno interregional. Los ricos indígenas del Collao $^{23}$ destruida su antigua economía vertical, recurren al Cusco para abastecerse del grano vital de los Andes. Así, en las bestias de los Collas, que tanto contribuyeron a estructurar ese mercado interno del sur, el maíz cusqueno supo de intercambios abundantes y Toledo ya evaluaba que en el maiz y las llamas estaban las fuentes del bienestar del país. ${ }^{24}$

Las mercancías enumeradas anteriormente pueden ser consideradas, incluso el maíz, dentro del sector dinámico de la economía regional, mercancías sustentadoras del mercado interno. Pero también. a un nivel jerárquico inferior, encontramos las mercancías yac llamaremos de circulación interna regional. Estas son las mercancías agrarias que acceden a un nivel de intercambios inferiores .ero con cierta dinámica propia: susceptibles de intercambio por otras mercancías (trueque) y no enteramente producto de las empresas agrarias, concluyen en el mercado urbano con relativa capacidad de engendrar ganancias. Podemos anumerar sin orden de jerarquía: papas, aves, huevos, chanchos, frejoles, carne, leche, que- 
so, frutas, conservas, cuero, ají, etc. . . El tono comercial y la bonanza económica de las mercancías producidas para ser realizadas fuera del espacio regional, permitía una presencia comercial de estas mercancías que eran intercambiadas en el ámbito rural, fuera del circuito monetario; pero que tenían salidas urbanas que merecen ser incluidas en el cuadro de la producción para el mercado interno.

Además de ser expulsor de mercancías, el mercado cusqueño es receptor de otras que lo vinculan con otras regiones. Los vinos de Arequipa son un claro ejemplo del dinamismo adquirido por la plaza cusqueña de mercancías. ${ }^{25}$ También el Cusco recibe, como todo el espacio peruano,la yerba mate del Paraguay ${ }^{26}$. Se consume pescado de Arica $^{27}$, chalona del Collao, mulas de Tucumán y finalmente los productos europeos que vienen de Lima como hierro, telas y consumo de lujo.

\section{La crisis de Potosí y el mercado regional cusqueño}

Ya no son tan sólidas las hipótesis que parten de una crisis "general" en Indias en el siglo XVI, a tono con la del mundo occidental. $^{28}$ Sin embargo, la escasa producción historiográfica para esta época, y sobre todo para el espacio peruano, no permite arribar a conclusiones certeras. La baja en la producción argentífera de Potosí, sin embargo, es una verdad ya demostrada. ${ }^{29}$ Algunos autores hablan de crisis ciesde 1610-35. ${ }^{30}$ Sin embargo, no es sino a partir de 1680 en que la baja es insostenible, hasta el punto mínimo ubicado entre 1715-1730. A pesar de ello, la retracción minera entonces no llegó a puntos incompatibles con la existencia de mercados regionales, aún dinámicos en el siglo XVII. El Cusco, por su cercanía y el producto mercantil sin competencia que ofrecía, mantuvo a lo largo del siglo un flujo constante de mercancías a Potosí que hace pensar en lo inadecuado del empleo del término crisis para la región. Por otro lado, la acumulación de riqueza obtenida en los tiempos del esplendor potosino, comenzó a revertir sobre la estructura urbana cusqueña por vía de las órdenes religiosas y los benefactores como aquel mecenas cusqueño que fue su Obispo, Manuel de Mollinedo. Así, una cierta autonomía regional, propia de la matriz regional,del mercado interno, se acentuó en el pe- 
ríodo de la crisis potosina. ${ }^{31}$ Por último, no es descartable que, aunque no haya sido el fenómeno dominante ri la única explicación de la consolidación de las haciendas rurales como sostiene Chevalier para México, ${ }^{32}$ una ruralización de la sociedad cusqueña de la segunda mitad del siglo XVII también es posible. ${ }^{33}$

El año 1720, una peste diezmó la población indígena, en el mismo momento que Potosí se encontraba en la época más baja de su producción. La coyuntura, sin embargo, no ha encontrado interlocutores de una posible crisis; es más, las descripciones de la importancia cusqueña y sobre todo la evolución de su población, indican el inicio de un nuevo período de bonanza, con Potosí recuperándose. En esta época del siglo XVIII, Cusco tiene ya una estructura colonial madura, capaz de resistir golpes y recuperarse al menor acicate del mercado. El máximo desarrollo orgánico regional llegó en 1770; a partir de ahí, una crisis en la producción de granos da paso al conjunto de cambios especiales que anteceden a la definitiva ruptura del mercado interno colonial.

\section{DESINTEGRACION Y CRISIS REGIONAL}

\section{Después de Lima: "la mayor ciudad de nuestra América Meridional". ${ }^{34}$}

Con esta expresión, que el geógrafo Cosme Bueno dedica a la Ciudad Imperial, queremos introducir el momento de la ruptura. En la segunda mitad del siglo XVIII, junto con el máximo esplendor de la ciudad del Cusco $^{35}$ comenzó un período de cambios en el conjunto de las relaciones del espacio peruano.

Internamente, el centro del Perú (como hoy lo conocemos) comenzó a desplazar al sur y al Alto Perú en la producción de plata. El Cerro de Pasco introduce un nuevo ciclo de "influencias distorsionadoras" como Mellafe calificaba a las de Potosi en el siglo XVI. Además, por medidas externas al espacio colonial, orientadas desde la metrópoli misma, ahora bajo la nueva administración de los 3 orbones implantadores del mercantilismo liberal más abierto que las colonias podrán tolerar, ${ }^{36}$ se liberalizan las importaciones y se crea en 1776 el Virreinato del Río de la Plata, incluyendo la au- 
diencia de Charcas dentro de su jurisdicción. Con ello, Cusco se encuentra en su camino con una competencia insoportable, sobre todo en su sector textil, de gran pujanza desde inicios del siglo y con un cambio en las orientaciones regionales de las mercancías. Carrio de la Vandera nos dirá al respecto: "y todo contribuye a la decadencia de una ciudad que se pudiera contar por la mayor del reino sin disputa alguna, por su situación, terreno y producciones, y rodeada de las provincias más fértiles y abundantes de frutas y colonos útiles, que son los indios que trabajan en el cultivo de las tierras y obras mecánicas y que atraen el oro y la plata de las provincias más distantes". 37

Pero en donde más influyen las reformas de Carlos III no es en el aspecto administrativo-político de la creación de un nuevo virreinato, que por lo demás refleja la hegemonía oceánica o litoral que América comienza a reflejar al advenimiento del capitalismo a nivel internacional. Lo que más influyó en los cambios económico-sociales de fines del XVI:I fueron las reformas, como el aumento de los impuestos, la racionalización de la administración fiscal haciéndola más eficiente y finalmente la supresión de los "repartos" de mercancías por parte de los corregidores. ${ }^{38}$ Aunque esta última medida fuera más bien consecuencia de la rebelión de Túpac Amaru, ya había sido planteada por los reformistas consejeros metropolitanos de la Corona.

Con todo, la crisis de finales del siglo XVIII no puede ser cabalmente comprendida si a todas estas variables nuevas en el conjunto del espacio peruano, no añadimos los propios mecanismos regionales que manifiestan el arribo a un tope en el desarrollo del modo de producir y el inicio de la decadencia.

La clave de esta hipótesis la encontramos en el mercado interregional del maíz. Para ilustrar esto, utilizaremos el ejemplo de una de las más importantes empresas maiceras del Cusco, la de los Bethlemitas. Llegados a Cusco en 1698, contaban con una importante hacienda maicera en Ollantay tambo por donación de un cercano colaborador del entonces obispo Mollinedo. Una vez establecidos, comenzaron a organizar su economía, que debía permitir el fluido funcionamiento de un hospital, la manutención de sus miembros, el boato de su "religión" y algunas remesas fuera de la región. Ya en 1709-10 el total de sus ingresos era de 12,597 pesos, 
de los cuales Sillque, la aludida hacienda maicera, proporcionaba 10,163 pesos. El periodo siguiente, en 1711, las cuentas arrojaron un aumento sustancial, creciendo sus rentas a 25,251 pesos de los cuales, $21,02.7$ pesos provenían de lo que la referida hacienda "dejaba libres". En los diez años siguientes, hasta 1721, los ingresos fueron de 161,530 pesos, con un promedio anual de 16,153 pesos; de los cuales, 95,663 provenían de Sillque, con un respectivo promedio anual "libre" de 9,567 pesos. ${ }^{39}$ Propio de una economía de tipo "pre-capitalista", las fluctuaciones anuales eran bastante grandes, pero, en sustancia, los ingresos provenientes de la comercialización del maíz eran base fundamental de la empresa Bethlemita que luego de estos años, engrandece sus propiedades y se convierte en un sólido concurrente en el mercado de productos agrarios para el mercado interno, intrarregional-urbano e interregional.

Sin embargo, entre 1797 y 1804 , el promedio anual de renta "libre" que llamaremos ieneficio total era sólo de 2,835 pesos, considerando en ellos un 190/o de los ingresos provenientes de arrendamientos que en los inicios del siglo XVIII no eran recurso común de los emprendedores Bethlemitas. ${ }^{40}$

¿Por qué se comenzó a recurrir al arriendo y las ventas arrojaban ganancias que descontada la inversión sólo llegaban a 1,533 pesos anuales, tan sólo el 160/o del promedio anual de 17121721? La respuesta está en la crisis del mercado interno de granos.

Hacia 1770. la curva de precios del maíz que muestran los registros de ventas de esta misma empresa, muestra el inicio de un largo ciclo de depresión. De precios promedio como $41 / 2$ pesos, llegando a 6 y 7 pesos en la primera mitad del XVIII y hasta 1770, la curva muestra promedios de $21 / 2$ con momentos de doce a catorce reales* que serán fatídicos a partir de esa fecha y hasta fines de la colonia. El año de 1771, en San Salvador, el arrendatario de la hacienda Uchumuca, el clérigo Juan Francisco Macedo, protesta no poder cumplir con el canon de 540 pesos para los propietarios que eran los mercedarios porque las 100 fanegas de trigo, puestas en la granja mercedaria de Kaira, en San Jerónimo, a la

\footnotetext{
- Cada peso tiene 8 reales.
} 
salida del Cusco para el Collao, que tributaba siempre como canon, no hacían "de manera alguna" el total del canon "siendo el año tan abundante de cosechas que se hallan los granos de todas las especies, en el prëcio más bajo". ${ }^{41}$

No se trata pues tan sólo de un. "ciclo juglar" entre 1770-80 ó 1776-1786 como sustentan Flores Galindo y Burga. ${ }^{42}$ Salvo el año de 1783 en que loṣ precios llegan a un máximo de 7 pesos por efecto de la rebelión, no hay puntos en la curva que superen los 3 p̉esos de ahí en adelante. ${ }^{43}$

En lo que sí aciertan Flores y Burga es en su apreciación acerca del aumento de la población y presión sobre la tierra, con subsecuentes migraciones que se manifiestan en el aumento de los "forateros", de suma importancia en las explosiones rebeldes de 1780$82 .{ }^{44}$ Es indudable que estos aumentos fueron explosivos, no sólo por los cambios administrativos en la fiscalidad sino también por el conjunto de efectos negativos para toda la estructura regional que la decadencia de los productos para la exportación generaban.

En esto, el énfasis no debe ser puesto sólo en la decadencia de los obrajes, o "industria textil" como también se los ha catalogado; sino más bien en el mercádo de granos como muy bien señala el Intendente Mata Linares: "El maíz que mantenía antes a los hacendados se halla hoy en tan bajo precio que ni aún les soporta los gastos de su siembra y colección".

En esa misma carta, fechada en 1786, Mata Linares anota lo que él supone causa del bajo precio: "que los indios del Collao que bajaban antes a proveerse de muchos miles de fanegas se han retirado desde la Rebelión. Van a otros partidos y no ha habido manera para que se vuelvan a su antiguo camino"45 Efectivamente, después de la Rebelión, un movimiento de cambio en los flujos de mercancías, llega a su fin. Para el Collao, los granos de Cochabamba y otras regiones del actual espacio boliviano, se convierten en sustituto del grano cusqueño. De la misma forma como el azúcar cusqueño pierde mercado por la competencia de la producción de Arequipa. ${ }^{46}$ Es decir, una serie de cambios especiales en el flujo de mercancías comienzan a presentar al Cusco como una región cada vez más estagnada; y en ello no sólo juega su papel el internamiento de mercancías externas y el robustecimiento litoral 
sino también el techo al que habían llegado algunas regiones en su respuesta al mercado interregional, que en conjunto comienza a entrar en crisis a principios del siglo XIX.

\section{La Renta de la Tierra: un indicador}

En la situación de retracción del mercado y de precios bajos, el alto grado de endeudamiento de los hacendados contribuyó a precipitar la ruina del campo cusqueño.

La grave situación por la que atravesaba el agro cusqueño queda graficada en un pedido que hicieron los hacendados de la región al Corregidor para que el rédito de los censos fuera rebajado. De este tipo de solicitud había ya un precedente, en 1707 , y la crítica situación que lo originó permite, por la semejanza del pedido, comprender el estado de las haciendas cusqueñas en los últimos 25 años del siglo XVIII. En aquella oportunidad, 1707, en Lima un acuerdo había fijado el rédito de los censos en un 3o/o, rebajándolo del 5o/o que por legislación de la Corona debian redituar los capitales censíticos. La medida obedecía a la calamitosa situación en que se encontraba la producción triguera de Lima y sus valles aledaños, originada en la crisis de la última década del siglo anterior y que tuvo como consecuencia más clara la conversión de Lima de exportadora en importadora de trigo. ${ }^{47}$ No sabemos cuánto duró esa concesión, pero lo cierto es que no era dable que se repitiera como práctica recurrente.

Semejante pues debió ser la situación de los hacendados cusqueños 70 años más tarde cuando solicitaron igual concesión. Según los hacendados demandantes, el maíz, que costaba en promedio 6 pesos por fanega durante la primera parte del siglo XVIII, en 1776 andaba por los 13 reales, y por ello demandaban rebajar las imposiciones a un rédito de 3o/o como medio para solucionar sus problemas. Pero corrían otras épocas y su petición fue denegada. ${ }^{48}$

Los hacendados, sin embargo, daban por hecho que el pedido sería aceptado, lo que a su vez apoya la hipótesis de la gravedad de la situación. Uno de estos hacendados fue don Vicente Centeno, que junto con su hermano, entonces Corregidor de Calca, eran los dos últimos descendientes de una importante familia terrateniente cusqueña. En una causa de acreedores abierta contra Vicente Cen- 
teno y su hacienda en Ollantaytambo, éste había solicitado al Juzgado Eclesiástico que se levantara el embargo trabado por los censualistas sobre sus bienes, pues lejos de deberles él réditos atrasados por imposiciones que alcanzaban los 49,112 pesos, éstos estaban "satisfechos y abanzados" porque los censualistas habían cobrado sus réditos "a razón de cinco por ciento, deviendo haberlos cobrado al tres por ciento". 49 Los acreedores, entre los que se encontraban los principales monasterios, continuaron con el juicio y la hacienda quebró, degradándose cada vez más su capital al punto que de 88,400 pesos en que fue tasada en 1776 , pasó a sólo 18,300 pesos en $1829 . .^{50}$

El caso de la evolución del valor de otra hacienda llamada Coroto en Lamay, ofrece otro magnífico ejemplo del impacto de la retracción del mercado y la crisis de precios sobre las rentas que recibían propietarios laicos y religiosos, asi como los arrendatarios de las tierras. Esta pequeña pero valiosa hacienda tenía, en 1653, en manos de don Pedro Jiménez de Toro, un valor de 25,000 pesos. De ellos, como la mayoría, si no todas las haciendas, tenía una parte comprometida a censo. En este caso eran 10,000 pesos a favor del Monasterio de Santa Catalina. Seis años después, en 1659, Jiménez de Toro vende la hacienda Coroto al Cura de Calca, Licenciado Tomás Núñez de Castro, en 21,000 pesos con 7,000 de ellos impuestos a censo a favor del referido Monasterio. Los clérigos, propietarios de los curatos, en esta época y hasta el inicio de la crisis, son propietarios rurales importantes, aunque en esta segunda mitad del siglo XVII, sospechamos por diversas evidencias que fueron un sector verdaderamente fundamental de entre los propietarios de tierras. Quizás éste sea un índice de ruralización, aunque no de crisis, para esta época.

No sabemos qué suerte corrió la hacienda en manos del cura Núñez de Castro, aunque no es dable suponer que haya sido mala por problemas de mercado. Lo que sí sucedía en estos casos era que las propiedades pasaban a patrocinar capellanías y eran administradas por albaceas de los curas, con lo que las haciendas atravesaban períodos de estancamiento sin propietario que velara porque no descreciera su capital. Este puede haber sido el caso de Coroto pues en 1741 la encontramos siendo objeto de remate público. No sabemos si por deudas del cura Núñez, por débitos del censo impuesto, o por el deseo de algún capellán de imponer el ca- 
pital en dinero, que significaba la tierra en otra hacienda o propiedad. No sabemos exactamente tampoco en cuánto compró la hacienda el ganador del remate, un abogado limeño llamado Juan de Berdugo, pero al poco tiempo, en 1744, sabemos que la vende en 20.000 pesos distribuidos de la siguiente manera: 2,500 pesos en efectivo, 9,500 pesos en el censo de Santa Catalina (que a su vez patrocinaba una cofradia), y 8,000 pesos que el comprador, un mercedario. se compromete a emplear en el arreglo de la iglesia de su congregación.

Como en el caso de Vicente Centeno, y coincidiendo con la época en que anotamos el techo del crecimiento económico agrario de la región cusqueña, en 1771. el Monasterio de Santa Catalina reclama 0,800 pesos de réditos adeudados por el mercedario, cifra que puede ser un poco exagerada. Lo curioso es que antes, en 1769. las monjas de Santa Catalina, propictarias de 9.500 pesos del capital de la hacienda, y de un nuevo capital constituido por los réditos adeudados, arriendan la hacienda por su cuenta. El monto del arrendamiento fue de 000 pesos, correspondiente al capital de sólo 12,000 pesos con que realmente habia sido comprada la hacienda. es decir, sin incluir los 8,000 de gracia de la venta anterior.

Con el estallido de la rebelión que fue muy fuerte en Calca, quizás tan devastadora como en Quispicanchis por ejemplo, las monjas consiguen que se les reconozca la propiedad y venden la hacienda en ruinas, por el valor de 7,500 pesos, es decir, sólo el $300 / 0$ del valor que tuvoan siglo antes. ${ }^{51}$

Las órdenes religiosas eran las principales propietarias de los censos y obras pias que pesaban sobre las haciendas; al quebrar las haciendas y devenir los réditos en "ditas incobrables", las cajas mayores de las casas religiosas cusqueñas comenzaron a verse en serios aprietos. Por otro lado, el sistema de arriendos en esa situación de retracción agraria acompañada de altas imposiciones, conducía a una degradación escandalosa del capital de las haciendas por causa de la depredación ocasionada por los arrendatarios criollos, que cada vez más eran parte de un grupo de chacareros de poca monta que fueron los únicos interesados en tomar en arriendo las haciendas.

Por ello se inauguró un sistema de ventas enfitéuticas. La fun- 
cionalidad de éstas era doble. Por un lado permitían salvar las haciendas de la degradación de su capital al incentivar a los chacareros criollos a invertir en ellas, ofreciéndoles una posesión a largo plazo (150 años). Y por otro, esta recuperación de las haciendas permitiría asegurar tanto el cobro de los cánones enfitéuticos como el pago de la mayoría de los censos y capellanías que de otra forma comenzaban a ser sólo escrituras de letra muerta, muchas de ellas con una antigüedad de cerca de 200 años. ${ }^{52}$ Este sistema por su parte ofrecía el nuevo panorama de la estructura de tenencia de tierra, pues los propietarios de la tierra sólo tenía derecho a una renta fija, mientras los verdaderos conductores, los enfiteutas, propietarios del "dominio útil" de la tierra, organizaron las haciendas criollas que dieron origen al gamonalismo republicano.

Las entradas de las cajas conventuales que los réditos de censos y cánones enfitéuticos generaban no encontraban, sin embargo, "fincas seguras" en donde imponerse. Muchas veces, las órdenes religiosas tenían que imponer los capitales en sus propias tierras, las más seguras de ellas, con lo que sencillamente hacían una inversión con riesgo propio y no ajeno como era costumbre. La estructura agraria atravesaba por una verdadera crisis.

\section{REGIONALISMO Y CRISIS POLITICA}

\section{El panorama hasta la rebelión de 1814}

Indudablemente que el último cuarto de siglo fue para el Cusco del XVIII la época crucial de sus cambios estructurales, aquellos cambios que dieron origen a la imagen de estagnación y marginación que el Cusco contemporáneo ha ofrecido. Hasta el momento hemos querido ilustrar con algunos indicadores el proceso de decaimiento de la agricultura cusqueña y la ruptura de los espacios internos de mercado que sustentaban aquella actividad económica y la de los obrajes. Sin embargo, conviene precisar cuál era la ubicación cusqueña en ese período de transición a la sociedad republicana posterior; cuál era su ubicación espacial, su importancia política y su imagen en el conjunto de esta sociedad colonial en proceso de desestructuración. 
John Fisher refiriéndose al movimiento de Túpac Amaru anota, entre las causas que impidieron un bloque entre indígenas y criollos que "aún si el apoyo criollo pudo darse en la sierra, fue casi inevitable que la hostilidad tradicional de la capital virreinal hacia Ios movimientos originados en el área del Cusco resultase suficiente para cortar la rebelión" 53 Esta "tradicional" hostilidad limeña era acompañada de una tuerte personalidad regional sur-serrana; no en vano la rebelión de Túpac Amaru, al margen de otras consideraciones que aun se encuentran en discusión, fue un movimiento regional violento, entre cuyas demandas estaba nada menos que la erección de una Real Audiencia en la capital andina. El establecimiento de la nueva Audiencia del Cusco en 1788 presidida por un burócrata español de tendencia conservadora fue un factor de relajamiento y alivio de las tensiones sureñas pues sus habitantes interpretaron el gesto como un estímulo para el renacimiento de la ciudad con un grado de independencia de Lima. ${ }^{54}$ El mismo Mata Linares, intendente de Cusco, reconocía en aquella reforma una importante medida para ganar la confianza de la ciudad y la región a favor de la Corona. Consideraba este funcionario peninsular de primera línea, que Cusco era una región estratégica, afirmando que "donde es más necesaria la tropa que en otras partes por las muchas consideraciones que ofrece esta ciudad (Cusco), ser la principal de lo interior de! Reyno, la cabeza que fue de los Incas y el entusiasmo que esto causa y en mi concepto tanto, que me atrevo a decir que aunque se perdiera Lima y Buenos Aires del Reyno aún se podrán recobrar, pero perdido el Cusco contemplo casi imposible su reconquista". ${ }^{5}$

A tınales del siglo XVIII quedaba claro que Cusco era una región estratégica, de suma importancia para controlar políticamente el espacio colonial que, después de las reformas, la rebelión y el inicio de un estancamiento, comenzaba a desmembrarse. Por eso la ciudad despertó tantos temores entre los funcionarios de la administración virreinal. Además, era claro que los cusqueños criollos y mestizos, la sociedad urbana y los propietarios agrarios, los comerciantes y los clérigos, todos, patrocinaban un sentimiento regional, una animadversión a Lima que comenzó a personificar, como vimos al inicio de este artículo para tiempos muy recientes, las causas de los males económico-regionales que empezaron a vivirse. ¿Por qué no comparar las celebraciones actuales del "día 
jubilar" de la ciudad con las manifestaciones de entusiasmo que el establecimiento de la Audiencia cusqueña despertó? En ambos casos, el júbilo tiene más bien motivos formales que reales.

Pablo Macera habla de un conjunto de "movilizaciones históricas" en que la consolidación de la hegemonía costeña culmina un proceso de larga duración. El primer momento de ese proceso es para Macera el de mayor desarrollo relativo del nor-ande durante todo el Formativo Temprano y Medio. Luego, un segundo momento, de generalización del desarrollo y multiplicación de los "polos de crecimiento" - término que usa Macera- desde el Formativo Tardío hasta el Horizonte Medio. Tercer momento, desplazamiento hacia el sur durante el Imperio Wari; cuarto, nueva generalización y multiplicación durante el II Período Intermedio; y quinto, un segundo desplazamiento hacia el sur con el Imperio Inca. ${ }^{56}$ Hasta aquí lo que el mismo historiador ha llamado nuestra "historia independiente". Luego, resulta sustantivo que la siguiente "movilización histórica" consignada por Macera, la primera de nuestra "dependencia", sea no la de un cambio de eje sino una preservación del sur durante los siglos XVI-XVIII, debido a Potosí y la concentración demográfica quechua-aymara; las mismas variables que consideramos nosotros al analizar la ubicación de la región cusqueña en lo que Assadourian y Garavaglia llaman el eje Lima-Potosí. Luego, desde mediados del siglo XVIII, se produce un séptimo desplazamiento histórico -siempre según Macera- hacia el Perú central, por dos productos de exportación, el azúcar y la plata de Cerro de Pasco. Frente a esto, el octavo período, que es el que ahora estamos tocando para el Cusco en este artículo, sería el de una "reacción sureña frustrada" cuyos hitos fundamentales son 1780, 1814 y 1836-39, ${ }^{57}$ Túpac Amaru, Pumacahua y la Confederación Perú-Boliviana.

"Los beneficiarios de la modesta expansión económica que experimentó el Perú en el período colonial tardio fueron los burócratas, los mercaderes, y, en menor grado, los mineros de Lima y su hinterland. La vida económica de las provincias del sur era llevada adelante esencialmente por la agricultura, que claramente no se expande después de 1784, y el comercio con el Alto Perú, que, se creía, podría recuperar su anterior importancia sólo con la reunificación de los dos Perú. El relativamente déhil sector minero 
en el sur, era activamente discriminado por las decisiones del Tribunal Minero, hegemonizado por los limeños, de concentrar sus limitados recursos hacia el desarrollo de Cerro de Pasco, una politica que provocó las ásperas protestas de los diputados por Puno en 1804". 58 Entre los años 1784 y 1795 la Intendencia de Puno pasó a formar parte del Virreinato del Río de la Plata, pero desde 1787. la Audiencia del Cusco ventilaba los casos de Puno ;9 Charcas, definitivamente, hasta 1810 pasó al referido Virreinato; estas separaciones, aunque no impedian el comercio, lo dificultaban, y la decadencia de esta actividad, del mercado en su conjunto, era objetivada como un efecto de la separación entre Alto y Bajo Perú. Desde ese momento, el sur conoció una serie de movimientos y demandas de carácter regional, como las protestas de los mineros puneños, que tuvieron en Cusco el "símbolo de la resistencia a Lima descle las guerras civiles entre Almagristas y Pizarristas".60

No es el momento de reseñar los distintos momentos en que se producen rebeliones y reivindicaciones regionales entre 1805 (Aguilar y Ubalde) y 1814 (Angulo y Pumacahua); sólo mencionemos que en las principales, la imagen del Imperio Incaico como fïgura ideológica fue recurrente. Por ejemplo, el general Castelli, comandante de las tropas patriotas rioplatenses, desde el Alto Perú cnviaba mensajes utilizando esta imagen para incitar el apoyo peruano a su causa. Dicha imagen no era sólo apelativa de los indigenas, lo era con más fuerza de la ciudad y la región que la personificaban; así, el Cusco como símbolo ideológico reflejaba al Cusce (omon núcleo de una antigua dinámica económica que los peruanos del sur recuperaban como alternativa. El momento cumbre será la movilización general del sur en 1814-15 encabezada por Angulo y Pumacahua. Movimiento separatista, patriota, que encerraba también un fundamental contenido regional. En su fracaso jugaron papel importante las fisuras sociales entre criollos e indigenas como ha enfatizado John Lynch, ${ }^{61}$ aunque la participación de los hermanos Angulo hasta el final de la rebelión, cuando los indígenas de Pumacahua, "los 300 mil incas señores de este suelo" con que José Angulo amenazaba a Abascal si usaba la fuerza contra Cusco habían sido derrotados en Umachiri, revela que, más que sólo constitucionalista, el movimiento de Angulo y sus seguidores fue verdaderamente nacional. ${ }^{62}$ Pero también, como muy bien lo ha señalado John Fisher, el rechazo limeño al Cusco 
y sus indios fue detonante de la derrota fundamentalmente nacional, pero también cusqueña. ${ }^{63}$

Frente a la ruptura de los espacios integrados del mercado pluri-regional que la colonia desarrolló en el espacio peruano, las regiones más afectadas reaccionaron con un movimiento regionalista; un sentimiento regional que en distintas manifestaciones ha permanecido incólume hasta la actualidad.

\section{Independencia y estagnación económica}

No vamos hacer un análisis, necesario según lo entendemos pero excesivo para estas notas, acerca del período que va de 1815 en que la "revolución" cusqueña y sureña fue derrotada y 1824 en que La Serna firma la capitulación española. Sólo conviene mencionar algunos elementos fundamentales para encuadrar adecuadamente un estudio histórico del regionalismo cusqueño.

Un primer análisis requiere la composición de los ejércitos que desde 1809 luchaban en el Alto Perú contra los intentos platenses de avanzar hacia el Perú por Charcas. Se trataba en mucho de tropas sureñas, incluso muchos de ellos fueron cusqueños llevados por el intendente interino de Cusco, José Manuel Goyeneche, que fue designado comandante de las tropas realistas del Alto Perú en 1809. Este "militarismo" cusqueño impulsado por la estructura colonial en declive fue también un mecanismo de movilidad social, frente al difícil cuadro de la producción y el comercio en esos años. Así, mientras en 1814 cinco años de guerra habían debilitado aún más las rutas comerciales alto-peruanas y la población sureĩa protestaba; otros sureños, esta vez enlistados en las tropas fidelistas, gozaban de una de las pocas oportunidades para obtener una posición económica por vía de los premios y de, por lo menos, alimento, vestido y salario. Cuando regresaron a Cusco en 1814 a debelar el levantamiento de sus paisanos, obtuvieron en premio tierras. ${ }^{64}$ No olvidemos hoy la importancia del ejército en nuestras sociedades, su presencia fue sin duda muy importante, junto con el repliegue mestizo y criollo, para pacificar la región. Luego, el establecimiento de la capital en Cusco, al abandonar La Serna su emplazamiento limeño, confirmó el rotundo cambio cusqueño hacia el bando realista, a pesar de que 
la esporádica capitalidad cusqueña le costó la final depredación agrícola y urbana por parte de las autoridades españolas.

La economía era calamitosa, y la derrota de los españoles no hizo sino abrir el panorama de la estagnación económica secular del Cusco. No en vano la Independencia esta vez vino de Lima. A todas las consecuencias económicas anteriores, añadamos las consecuencias de la depredación guerrera $y$, por último, la apertura definitiva del mercado sur andino a la invasión de mercancías inglesas. ${ }^{65}$

Ante los cambios en el mercado, inducidos por el imperialismo inglés y la oceanización de los flujos comerciales, el Cusco dejó de ubicarse en un espacio estratégico, convirtiéndose Arequipa en el nuevo eje regional del sur. ${ }^{66}$ El nuevo capital comercial, sin embargo, basó su circulación en un aparato productivo menos dinámico, desarticulado, en donde las haciendas ganaderas reemplazan a las graneleras y azucareras como agentes de dinámica mercantil, y con un desplazamiento, del Cusco hacia el altiplano, de las zonas productoras mercantiles básicas, salvo esporádicos intentos de la selva alta.

\section{Las respuestas federalistas}

Pero este proceso recién comienza a cuajarse después de 1850; antes el Cusco no había dejado de aparecer en la escena demandando la reconstrucción de su antiguo mercado. Ya separados los espacios Peruano y Alto Peruano (Boliviano), no sin algunos intentos contrarios de unidad, el regionalismo cusqueño comienza a adquirir rasgos de federalismo.

El regionalismo estructural como fenómeno de disloque no solucionado tuvo como expresión política el federalismo. Gamonalismo y federalismo fueron dos características del regionalismo cusqueño. El primer elemento como factor distorsionante básico de las relaciones estructurales de producción y de dominio, fue un reemplazo localista y patriarcal de la antigua "faceta oriental", del control burocrático de todo el espacio de dominio colonial. Roto ese elemento estatal centralizador, sea cual fuere su carácter, aparece un control local, un poder casi omnímodo de los propietarios rurales, esta vez desvinculados del mercado interno y cen- 
trando sus esfuerzos en la cómoda obtención de una renta en especies y trabajo de los indígenas sometidos a servidumbre. Otra ruralización social que Tamayo ha calificado de rearcaización, ${ }^{67}$ que marcó definitivamente el devenir del Cusco contemporáneo.

A diferencia de la persistencia y enraizamiento del gamonalismo, el federalismo sólo tuvo expresiones esporádicas cuyo estudio está aún por hacerse. Aunque ambas expresiones sociales, una a nivel infraestructural y la otra a nivel político, fueron productos de una época y estuvieron vinculadas, no podemos afirmar que, cuando aún estaban frescos los recuerdos y las vivencias de aquel mercado interno macrorregional en que Cusco jugó papel aglutinante y estratégico, se tratara de fenómenos complementarios. El gamonalismo era un producto nuevo que subsistió en la medida en que el Perú siguió siendo una yuxtaposición relativamente caprichosa de regiones dislocadas; ${ }^{68}$ pero el federalismo, embrionario y sin sólidas bases de sustentación, era más bien un producto reactivo, buscaba rescatar parte de la estructura perdida, si no toda ella. Luego, abolido el tributo indígena, iniciada la construcción de una red de ferrocarriles y caminos, perdida la guerra del Pacífico y toda posibilidad de unificación de los "dos Perús", en pleno tránsito al capitalismo dependiente: el federalismo, como lo calificara Mariátegui, no era sino otra cara del gamonalismo; como hasta hace un año, una agrupación política casi folklórica, todavía lo planteaba. Sin embargo, conviene establecer, para una futura investigación, la época en que el Cusco podía ser regionalmente, sin implicar retrocesos históricos, patrocinador de federalismos.

La más conocida de entre las primeras intenciones federalistas es la de Escobedo en 1830. Poco se sabe al respecto y alguien ha dicho que era más bien un movimiento "confederalista" tras el cual se encontraba el general Gamarra. Y entre 1834-36, aquella "anarquía" invocada para la intervención boliviana que dio paso, por el camino equivocado de acuerdo a Basadre, a la Confederación Perú-Boliviana; los contenidos regionales fueron parte activa de la lucha. Basadre nos dirá al respecto: "Aparte del contenido nacional que dio a esta guerra Salaverry, ella tiene además cierto contenido regional. Salaverry representaba a Lima y, en ge- 
neral, a los departamentos del norte. Una de sus proclamas, frecuentemente glosada por los periódicos del sur que le eran hostiles decía: "La empresa es limeña y, por consiguiente, justa y noble". Las letrillas transcritas y otras expresaban el desdén y el orgullo costeños y, sobre todo, limeños ante la intromisión del serrano Santa Cruz con sus huestes del altiplano."69

El efímero Estado Central del Perú que formara el Mariscal Gamarra con capital en Cusco no sólo obedecía a las maniobras que este caudillo venía fraguando al lado de Santa Cruz contra Orbegoso; también respondía a un espíritu presente entre los pobladores.. $^{70}$ La derrota de Gamarra en Yanacocha no fue el final de ese intento federalista. La Confederación fue la máxima expresión del mismo. Cusco nuevamente fue capital de un Estado, el Sur Peruano, y al decir de Tamayo fue ésta una época próspera. ${ }^{71}$ Esta vez, los "dos Perús" se volvían a integrar dando al país una fisonomía definitivamente andina, indígena y sureña. El viejo mercado, el escenario étnico y cultural de nuestro intento nacional, estaba restablecido y el Cusco estaba sobre el camino de la recuperación. Santá Cruz se preocupó de la decadente industria textil ordenando los uniformes del ejército a los obrajes cusqueños; como ya lo había hecho en su corta magistratura peruana casi diez años antes. El General Ramón Herrera mereció el aprecio cusqueño por su labor como presidente del Estado Sur Peruano como lo muestra la biografía que los miembros del Centro Científico del Cusco publicaron en $1907 .{ }^{72}$

No se puede abordar en unos párrafos la complejidad de la Confederación. Pero, para el Cusco fue la última oportunidad. La paradoja de su destrucción es muy indicativa. En 1839, en Yungay, Gamarra derrota a Santa Cruz, devolviendo la traición de que fue objeto en Yanacocha; pero esta derrota inflingida por una expedición chilena contra el vínculo de Perú y Bolivia, no impidió al Mariscal cusqueño intentar la instauración, desde el Perú, de la Confederación. Quien lo derrotó, el caudillo boliviano Ballivian, no era tampoco contrario a los vínculos federales del sur con Bolivia, y por su cuenta inició otra campaña de conquista que el regionalismo limeño y norteño derrotó, sellando para entonces la identidad entre sus intereses y los de la nación. ${ }^{73}$ 


\section{MARIATEGUI Y LA ESCUELA CUSQUEÑA: REGIONALISMO Y CENTRALISMO}

El conocido nombre de Escuela Cusqueña que García Calderón dio a la generación cusqueña de la primera década de este siglo, esconde un largo proceso histórico. Los conocidos Valcárcel y Uriel García, el Grupo Resurgimiento de los años veinte tan promocionado por Amauta, no fueron producto del azar. Ya se ha sustentado que desde finales del siglo anterior y durante los primeros lustros del presente, un grupo local, una burguesía regional, buscaba canales orgánicos de expresión a la par que consolidar su posibilidad estructural de existir. ${ }^{74} \mathrm{El}$ canal más importante de este grupo también vinculado a la universidad, todavía muy elitista, fue el Centro Científico del Cusco. Su existencia, desde 1897, estuvo orientada a patrocinar la conquista de la ceja de selva; se trataba de una elite regional que hacía esfuerzos por desarrollar su región básicamente pensando en el comercio y la agricultura. Tanto no eran un apéndice del Cusco gamonal que, lejos de suscribir federalismos oportunistas, sustentaban, en su épica conquista de la selva, una clara "identidad con el Perú". 75

El debut de nuestra centuria nos ofrece el panorama de una robusta comunidad intelectual, muy vinculada con estos últimos intentos verdaderamente progresistas de reconstruir el antiguo ámbito cusqueño y liberar la región de las ataduras del retraso de más de 70 años de vida republicana. Pero lo más importante es que, una de las imágenes ideológicas más unificadoras y vivas que supieron levantar fue el regionalismo, un regionalismo de nuevo tipo que Mariátegui reivindicó en su ensayo sobre "Regionalismo y Centralismo".

M:1ariátegui sustentó en esa época una imagen muy coherente del problema. Por supuesto que su información colonial, basada en impresiones poco científicas le impedía ver el panorama regional con mayores elementos de juicio, lo que le hizo concebir una imagen negativa, propia de su momento histórico, del regionalismo expresado hasta entonces y desde el inicio de la vida republicana como federalismo. Para el Amauta, el sur era el conjunto regional más definido del país, pero afirmaba que no existían regiones claramente definidas. Este erà un primer elemento limitante del regionalismo que hace de este sentimiento, un malestar carente de ca- 
nales de expresión. Esta afirmación es parcialmente cierta, pues, si bien no se podía en el contexto de los departamentos contemporáneos esbozar una descentralización homogénea, tampoco se trataba, desde el propio punto de vista mariateguista, de una descentralización-centralista que implicara rupturas de tipo separatista.

Para Mariátegui habían cos grandes problemas políticos que hacían abstracción de la historia anterior a su imagen contemporánea de la República Aristocrática. El Federalismo, como expresión oportunista del gamonalismo coludido con el centralismo, era un canal de expresión retardatorio que no podía concitar la atención de los grupos sociales de avanzada. Esta idea tuvo una clara respuesta de parte del grupo cusqueño por voz de Luis Eduardo Valcárcel: "Corrientes federalistas -escribió Valcárcel- las hubo en el Perú desde los primeros años de la República. La revolución de Escobedo en el Cusco en el año 1830 tenía ese carácter. Gamarra, destructor de la Confederación Perú-Boliviana, era ferviente federalista. El núcleo de departamentos meridionales (Cusco y Arequpa a la cabeza) mantuvo siempre definida resistencia al centralismo limeño. Cosa distinta es que la palabra sirviese de señuelo a ciertas agrupaciones caudillescas; pero no puede negarse que la tendencia a federalizarse arranca de profundas raices populares". ${ }^{76}$

Esto no implica, sin embargo, sustentar el federalismo, como el propio Valcárcel se encargó de aclarar al adherir al indigenismo que encontraba en los postulados mariateguianos, identificándolos con su propio credo "serranista" e "indiófilo". Pero la aclaraciỏn era necesaria y no podía provenir sino de alguien que todavía administraba ideológicamente los intereses regionales de una burguesía sin canales de consolidación.

La posición que patrocinaba Mariátegui estaba vinculada con su tesis central del problema ind-ígena y el problema de la tierra. Solucionar el problema del indio era solucionar el problema de la tierra, barrer el gamonalismo y sus expresiones decadentes como el federalismo era parte de una regeneración del Perú, hacia un descentralismo de "nuevo tipo", un centralismo democrático. Este segundo problema político está basado en el supuesto de que el regionalismo vago que nuestras indefinidas regiones incuban se funde en un dualismo básico: costa española versus sierra ind ígena. Siendo el sur, definitivamente serrano, era claramente indígena; por 
eso, era la región más clara de nuestro país. ${ }^{77}$ En terminos políti$\cos$ y en esencia la afirmación es totalmente correcta. Pero se mueve a nivel de una extrema generalidad.

"Regionalismo no quiere decir separatismo" dice Mariátegui, y Valcárcel complementa que "federalismo" no es necesariamente antipopular. Ambos postulados obligan a una particularización del planteamiento mariateguiano de subsumir el regionalismo a la solución del problema de la tierra. Hoy, no está "solucionado" el problema de la tierra, pero las condiciones de la lucha política son muy diferentes: y el regionalismo sigue latente como hemos visto.

El hecho de que Mariátegui haya mantenido fraternas relaciones con Valcárcel y por su intermedio con el grupo cusqueño, muestra que el regionalismo básico de las posiciones cusqueñas estaba dentro de las evidencias con que contaba Mariátegui. Que haya querido resaltar el indigenismo de Valcárcel, más que su regionalismo, sin percatarse de un cierto retroceso en las posiciones del intelectual moqueguano-cusqueño; no resuelve el problema. En 1814, el "problema del indio" que era el "problema de la tierra" impidió el éxito de la Revolución, pero ello no oculta que las tensiones regionales hayan sido factores desencadenantes del inicio y del fin de la misma.

En estas notas hemos querido plantear hipótesis de trabajo. La perspectiva histórica rebasa los estrechos marcos de la planificación burocrática que hoy hace suyo el problema regional aún presente. El devenir de una clara región de nuestro país, en donde los problemas básicos de la constitución de nuestra formación nacional se hacen presentes, es un buen camino para la investigación del Perú. Hoy, la historia del norte, que no es otra que la del capitalismo en el Perú, ha allanado el camino para que la masa de productores integrada en el mercado y el pueblo mestizo del interior sean una nueva fuerza, cuya historia, la historia del sur, contribuya a la definitiva constitución de una nación peruana en una nueva sociedad. La memoria del sur es parte de la identidad nacional en formación. 


\section{NOTA S}

1/ MARIATEGUI, José Carlos: "Regionalismo y Centralismo". en 7 Ensayos de Interpretación de la Realidad Peruana. Biblioteca Amauta - Lima, 13. Edición. 1968. Pág. 165.

21 Ibid. Pág. 154.

3/ BROMLEY, R. J.: "Precolonial Trade and the Transition to a Colonial Market System in the Audiencia of Quito". en Nova Américana No. 1. Torino, 1978.

4/ ". . si Jefinimos a la actividad del núcleo potosino - con el agregado de Lima como centro monopólico de importa. ción/exportación - como la que concita el conjunto de las relaciones económicas regionales, es evidente que todo cse conjunto debería danzar al compás - assai moderato- de la unidad dominante". GARAVAGiLIA, Juan Carlos: "Un capítulo del mercado interno colonial: el Paraguay y su región (1537-1682)". en Nova Americana No. 1. Torino 1978. Pág. 49.

5/ ASSADOURIAN, Carlos Sempat: "Integración y Desintegración Regional en el Espacio Colonial: Un Enfoque Histórico". en Revista Latinoamericana de Estudios Urbano Regionales, EURE No. 4. Santiago de Chile 1972. Pág. 11.

6/ Un cesto de coca, de 15 pesos en 1549. baja a sólo 2.5 pesos en 1560 y la tendencia continuó debido al aumento de las áreas de cultivo. Ver MELLAFE. Rolando: "Frontera Agraria: El caso del Virreinato Peruano en el Siglo XVI", en Jara. Alvaro (Ed.): "Tierras Nuevas". México 1969, Pág. 27.

7/ GAKENHEIMER, Ralph: "The Early Colonial Mining Town: Some Special Oportunisties for the Study of Urban Structure", en Urbanización y Proceso Social en América, IEP. Lima 1972. Págs. 361-362.

8/ MELLAFE, Rolando: "Comentario", en Latin American Research Review. (L.ARR) 5:3,1970, Pág. 95.

9/ En 1530 de una población estimada en 2'738,673 habitantes, la sicrra sur. lo que llamamos andes centrales, tenía 1 'o(1)3.832; es decir un 37\%/o. Y en 1630 . en pleno desastre demográfico. de 601.645 habitantes totales, la sierra sur albergaba a 311.557 de ellos, el 520/o. Según las estimaciones de COOK. Noble D.: "The Indian Population of Perú 1570-1620". PH.D. University of Texas at Austin. 1973. Pág. 304. El Collao y Cusco, sobre todo su ámbito sureño. destacan como centros de alta densidad demográfica.

10/ MORNER, Magnus: "Notas sobre el Comercio y los Comerciantes del Cusco", IEP, Lima 1979, Pág. 12.

$11 /$ MELLAFE, R.: "Comentario" op. cit. pág. 96.

121 MORNER, M.: "Notas sobre. . ." Op. cit. Pág. 12.

$13 /$ Aunque para el siglo XVIII, la "Relación de la fundación de la Real Audiencia del Cusco" de Ignacio de Castro resulta ilustrativa cuando dice: "el comercio en sus amplísimas ramas de importación y exportación trasciende a casi toda la ciudad".

$1 \mathrm{t/}$ "Las ciudades son como transformadores eléctricos: aumentan las tensiones, precipitan los intercambios, traman continuamente la vida de los hombres. Han nacido de la más antigua y más revolucionaria división del trabajo: las tierras de labor por un lado. las actividades llamadas urbanas por otro". BRAUDEL. Ficrnand: Barcelona 1974, pág. 381.

$15 /$ "Las Haciendas de los altiplanos yue producían en primer lugar cereales (incluso el maiz) y ganado. surgieron y se desarrollaron como grandes empresas agrarias en estrecha dependencia de mercados nuevos o adicionales. Se constituían siempre en épocas en que se abrían para ellas mayores centros de consumidores y mercados de salida. Estos mercados se encontraban en las regiones de los altiplanos latinoamericanos sobre todo en las empresas mineras explotadas con actividad febril desde la conquista, como en las recién fundadas ciudades españolas en expansión". LIEHR. Rainhard: "Orígenes, evolución y estructura socioeconómica de la hacienda hispanoamericana". en Anuario de Estudios Americanos, Tomo XXXIII, Sevilla 1976. pág. 547.

16/ Acerca de los distintos mecanis- 
mos de acceso a la tierra y el fin de la época de frontera agraria para dar paso a la del latifundio, ver MELLAFE, Rolando: "Frontera Agraria. . " pp. cit.

17/ La tesis es sustentada por ASSADOURIAN, Carlos: "La Producción de la Mercancía Dinero en la Formación del Mercado Interno Colonial" en Florescano. E. (ed): Ensayos Sobre el Desarrollo Económico de México y América Latina (1500-1975)". Fondo de Cultura Económica (FCE), México 1979. pp. 291-292.

18/ LOCKHART, James: "Encomienda and Hacienda: The Evolution fo the Great Estate in the Spanish Indias". En Hispanic American Historical Review (HAHR) 49: 3, i969, pág. 429.

19/ Ver KLEIN, Herbert S.: "Haciendas y Ayllus en el Alto Perú - Durante ei Siglo XVIII", en Tulio HALPERIN (ed): El Ocaso del Orden Colonial en Hispanoamérica. Ed. Sudamericana. Buenos Aires 1978, pág. 21. Las referencias a la coca cusqueña en el siglo XV! son numerosas.

20/ El funcionamiento mercantil de las haciendas azucareras es estudiado por POLO y LA BORDA, Jorge: "La Hacienda Pachachaca: Autoabastecimiento y Comercialización". Lima 1976. La fama de la producción azucarera cusqueña de los siglos XVI y XVII es analizada por ASSADOURIAN, Carlos: "Sobre un elemento de !a economía colonial: Producción y circulación de mercancías en el interior de un conjunto regional".. en EURE No. 8, Santiago de Cinile 1973. pág. 144. 21/ La imporiancia de los obrajes está establecida por muchas descripciones dei siglo XVIII que son cxcritas cuando este sector pujante entró en decadencia. Ver las fuentes de FLORES GALINDO. Al'.erto: "Arequipa el Sur Andino: Siglos XVIII - XX". Horizonte. Lima 1977. pp. 20-21;37-4().

22/ Sobre la importancia del maíz ver ASSADOURIAN: "Sobre un elemento. . "op. cit.. Pp. 141-143. También GLAVE, Luis Mliguel y REMY. Maria Isabel: "La producción de Maíz en Ollantaytambo durante el siglo XVIII". en Allpanchis No. 15. Cusco 1980, Pp. 1(19-132.

23/ ASSADOURIAN, Carlos: "Sobre un elemento. .." op. cit. pp. 160-161.

24/ PIETSCHMANN, Richard: "La Historia Indica", UNMSM, Lima 1964. Pág. 20.

25/ Los protocolos notariales del siglo XVI que se conservan en la Biblioteca Nacional (dos) y en el Archivo Histórico del Cusco (en adelante AHC), son muy ricos en esta información. Ver también Keith Davies: "The Rural Domain of the City of Arequipa, 1540-1665". Ph. D. University of Connecticut 1974.

26/ GARAVAGLiA, J. C.: "Un Capítulo..." op. cit.

27/ ASSADOURIAN, Carlos: "Sobre un elemento. .." op. cit., Pág. 164.

28/ Al respecto ver BRADING, David: "El mercantilismo ibérico y el crecimiento económico en la América Latina del siglo XVIII", en Florescano (ed): "Ensayos. .." op. cit.. pág. 302-303.

29/ MOREYRA. Manuel "En torno a dos valiosos documentos sobre Potosí", en Revista Histórica, Tomo XX, Lima 1953.

30/ GARAVAGLIA: "Un Capítulo. .." op. cit.. Pág. 48.

$31 /$ "En cuanto a los efectos (de la crisis potosina) sobre el conjunto anteriormente controlado por el eje peruano, en este caso, asistimos a una autonomización creciente, tanto desde el punto de vista productivo como en la orientación del Tráfico". Ibid. p. 50.

32/ CHEVALIER, Francois: "La formación de los latifundios en México. FCE, México 1976.

33/ En su "Prólogo" a las "Noticias Cronológicas de la Gran Ciudad del Cusco". Biblioteca Peruana de Cultura, Lima 1980; Félix DENEGRI llega a calificar el siglo XVII cusqueño como "una verdalera edad de oro". Aunque se trate sólo de una intuición de un conocedor. las evidencias refieren que de ninguna manera el siglo en cuestión fue tiempo de crisis regional para el Cusco.

$3+1$ Citado por DENEGRI, ibid.

35/ Refiriéndose al Cusco y al desarrollo de su arte. Pablo Macera afirma que se debe al: "grado de relativa autonomía regional respecto al centro vicemetropolitano. Es cierto que Lima era "garganta" del Perú y que todo se le relacionaba. Pero 
no con igual intensidad. En ciertas ocasiones al lado de la "economía hacia afuera". hacia Lima y sus rutas marítimas, se estructuró una economía regional próspera con sus propios circuitos internos. En estas zonas, además, las distancias toleraban un mayor margen de iniciativa en la administración". "El Arte musical cusqueño siglos XVI - XX". Trabajos de Historia "T II. 1977. Pág. 460. Respecto a la pobla. ción del Cusco. la-ciudad tuvo en 1792 casi 32.000 habitantes; MORNER: "Notas sobre. .." op. cit. pág. 12.

36/ BRADING: "El mercantilismo"... op. cit.

$37 /$ CARRIO de la Vandera: "El lazarillo de ciegos caminantes". Biblioteca de Autores Españoles, No. 122. Madrid 1959.

38/ FISHER. John: "La Rebelión de Túpac Amaru y el Programa de la Reforma Imperial de Carlos III". en FLORES GALINDO (ed) "Sublevaciones populares y sociedad colonial". INIDE. Lima 1976. Sobre los repartos de mercancías ver GOLTE, Jürgen: "Repartos y Rebeliones". IEP. Lima 1980.

39/ AHC - Archivo del Colegio de Ciencias (en adelante ACC). Topo 33. Legajo 3, f 6ú.

4U/ GLAVE - REMY op. cit.. pág. 119.

41/ Archivo Arzobispal del Cusco (en adelante AAC): Caja 43. Paquete 317. Expediente 19.

421 FLORES GALINDO, Alberto $y$ BURGA. Manuel: "La Producción Agricola $y$ las sublevaciones durante el siglo XVIII", en Anales Científicos de la Lniversidad del Centro No. 4. Huancayo 1975. Pág. 176.

43 Respecto a los precios "exorbitantes" del tiempo de la rebelión ver los comentarios del prefecto Bethlemita en AHC-ACC. Top. 5. Leg. 5. "Libro de Principales". t. 29.

tt/ Ver tambien: CORNBLIT Oscar "Levantamientos de Masas en Perú y Bolivia durante el siglo XVlll", en Tulio Halperin: "El ()caso. . ." op. cit. Págs. $5 i-121$.

+5. Citado en MORNER: "Notas

whic.." op. cit. Pag. 9.

to P(ILO ! LA BORDA: "I.a Ha. cienda Pachachaca. . " op. cit.. pág. 96 47/ RAMOS. Demetrio: "Trigo chileno. navieros del callao y hacendados limenos entre la crisis ayrícola del siglo XVII y la comercial de la primera mitad del siglo XVIII". Instituto Gonzalo Fernández de Oviedo. Madrid 1967. Pág. 31.

48/ AHC-ACC. Top. 17. Leg. 2. A pesar de no ser exactas. las cifras que proporcionan como "promedios" los hacendados, no son descabelladas.

491 AHC - Fondo Vega Centeno. Real Hacienda, Leg. 7. 1804: Concurso de Acreedores, Hacienda Huatabamba, f 52.

50/ AHC - FVC - RA, cit. y Protocolo Pablo Mar y Tapia 1829-33, ff. 97v-99v. 51/ AAC caj. 26 - Paq. 275. Leg. 3 años 1779; Caj 27 - Paq. 278, Leg. 8. año 1782 .

521 La situación era tan calamitosa que no se podían arrendar las haciendas sin un desmedro demasiado alto de sus capitales. Incluso. las haciendas que eran conducidas directamente sufrían una sensible baja en sus rentas. Así, mientras la renta oficial de los capitales seguía siendo 5o/o, una hacienda muy valiosa como Pachar en Urubamba, sobre un capital, o "principal" como lo acostumbrahan llamar los contemporáneos. de 25 .000 pesos la renta era sólo de $700 \mathrm{p}$. anuales. es decir, sólo el $2.80 / 0$. Y la conducción corría todavía a cargo de los mismos propietarios. (AHC - ACC, Top. 27. Leg. 1.f $56 \mathrm{v}$ ).

53/ FISHER John: "La Retielión de Túpac Amaru. . ." op. cit.

54/ FISHER John: "Royalism, Regionalism and Rebellion in Colonial Perú. 1808-1815", en HAHR 59:2. 1979. $P a_{i} \cdot 239$.

55/ Citado por FLORES GALINDO $y$ BURGA: "La Producción. . ." op. cit.. Pág. 238-239.

56/ MACERA, Pablo: "Plantaciones Azucareras Andinas", en Trabajos de Historia. Tomo IV. Lima 1977. Págs. 118 119.

571 Ibid., Pág. 119.

58/ FISHER, John: "Royalism.

op. cit., Pág. 240.

59/ HAMNETT. Brian: "Revolucióny" 
Contrarrevolución en México y el Perú", FCE, México 1978, pág. 184.

60/ FISHER: "Royalism. . " op. cit. Pág. 249.

61/ LYNCH, John: "Las Revoluciones hispanoamericanas 1808-1826", Ariel, Barcelona 1976.

621 HAMNETT, B.: "Revolución. .." op. cit.

63/ FISHER: "Royalism..."op. cit.

64/Ver la ponencia de José TAMAYO HERRERA al V Congreso de Historia de América. Publicaciones de la Comisión del Sesquicentenario de la Independencia Nacional. Lima 1971, Tomo III, Págs. 382-398.

65/ BONILLA, Heraclio: "Comercio Libre y Crisis de la Economía Andina": el caso del Cusco", en Histórica - Vol. II, No. 1, PUC Lima 1978. Hace incidencia en el comercio libre como origen de la crisis. textil sobre todo, de la economía cusqueña. Coimo hemos visto, el problema llevaba muchos años y la introducción más pronunciada de textiles ingleses después de la Independencia no fue el único motivo a tenerse en cuenta para analizar la crisis de la economía andina, aunque tampoco sea de segunda importancia sino todo lo contrario.

66/ FLORES GALINDO, Alberto: "Arequipa y el sur. .." op. cit.

$67 /$ TAMAYO HERRERA, José: "Historia Social del Cusco Republicano", Lima 1978, Pág. 57. El estudio de Tamayo Herrera es el único de tipo regional desde la perspectiva histórica que se ha hecho sobre el Cusco contemporáneo. El capítulo: "El Cusco del Siglo XIX" ofrece un buen resumen de las informaciones editadas y de difícil acceso para esta época; ibid. págs. 31-87.

68/ Jorge BASADRE sostiene, en base a la discusión política de 1827-35, que las afirmaciones de que el Perú al concluir la dominación española era un "archipiélago" de regiones autónomas son de "gran audacia" y poco probables. Ver: "Bases Documentales" Tomo I. Págs. 192-201. Nuestra afirmación de que los tiempos tempranos de la República son todavía para el Cusco una época de posibie reconstitución implica una relativa uniidad del tipo de la desarrollada en la colonia. Por otro lado, la forma como los periódicos cusqueños de la época enfocan los problemas nacionales así lo revela. Respecto al tema, Bonilla, Heraclio: "Islay y la economía del sur peruano" en Apuntes No. 2, Lima 1974, Pág. 32 dice: "muy difícilmente se puede llamar nación peruana a la yuxtaposición de diversas regiones... pero yuxtaposición no quiere decir desarticulación total".

69/ BASADRE, Jorge: "La Iniciación de la República", Biblioteca Peruana. Lima 1929, Tomo 1, Pág. 391.

70/ Antes, al mando del coronel Manuel Lopera, estalló un movimiento contra Orbegoso que adhirió a Salaverry. No bien llegaron las tropas de éste el movimiento se puso al servicio de Gamarra quien al llegar al Cusco el 9 de junio de 1835 manifestó: "Al repasar el Desagualero, fui instruido de que la cuna de los Incas ocupada por una soldadesca insolente, padecía numillaciones inmerecidas, me decidí a cumplir con el más grato de mis deberes". El día 13 de ese mes formó el Estado Central del Perú compuesto de los departamento de Cusco, Puno, Ayacucho y Arequipa. Ver: "La Revolución de Lopera y el efímero Estado Central del Perú". Compilación de Horacio Villanueva, en. Revista del Archivo Histórico del Cusco No. 12, Cusco 1967, Págs. 59-165. La colección de bandos y periódicos de la época se conserva en la Biblioteca de la Universidad San Antonio Abad a cargo del Sr. Adrián Valer.

71/ TAMAYO HERRERA: "Historia..." op. cit.

72/ La dificultad de adquirir en Lima el boletín de esa institución está salvada por la publicación de la biografía mencionada, por Félix Denegri Luna, en Revista Histórica Tomo XXIX, Lima 1966. Respecto al Centro Científico del Cusco ya contamos con el estudio publicado por José Luis RENIQUE en Histórica Vol. IV. No. 1, PUC, Lima 1980.

$73 /$ Ver DENEGRI Luna, Félix (ed): "Protocolos de las Conferencias de Vilque y Puno (1842)", en Revista Histórica Tomo XX". Lima 1953., Págs. 109-128.

74/ GLAVE. Luis Miguel: "El Cusco en el primer Tercio del Siglo XX? , Centro Las Casas, Cusco 1978. 
75/ RENIQUE. Josk Luis: "El Centro Cientifico del Cumo 1897-1907", en Histórica, Vol. IV. No. 1, PUC, Lime 1980. Pág. 46. Sumane tace y otras interesantes hipóteris cerren de exte poco conocido organismo ideolbgico cusqueño.

76/ VALCARCEL. Luis E.: "Un Libro de Mariátegui". en Amauta No. 23, Lima 1929. Pág. 85.

$77 /$ MARIATEGUI, Jose Carlos: "Regionalimo y Cearadiamo" op. cit. Pp. $154-180$. 